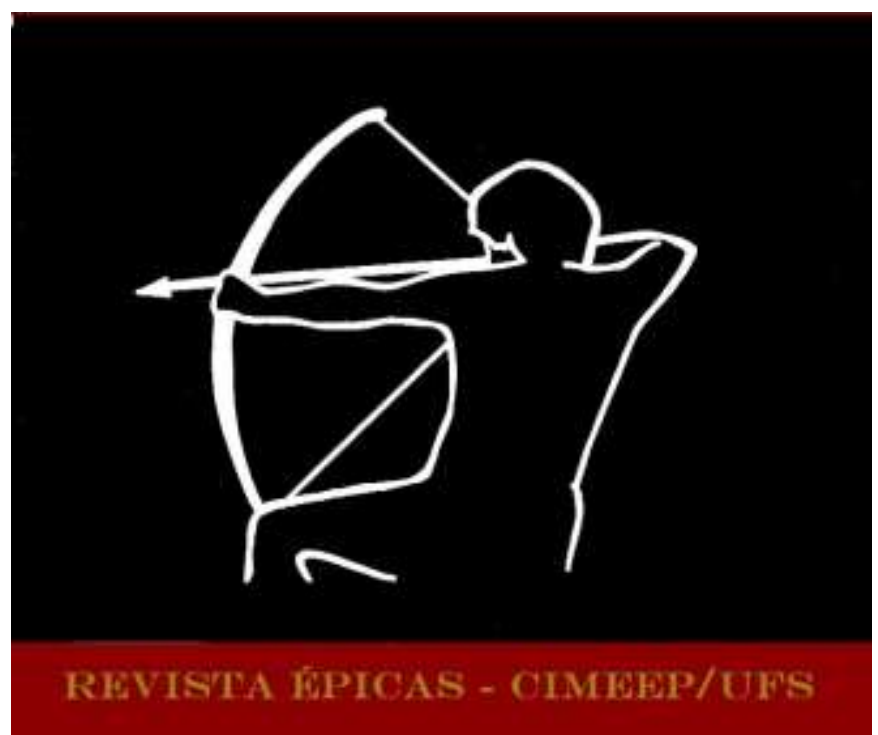

BARTH, Vinicius Ferreira. Contemplação nas sombras: $O$ guesa de Sousândrade e a meia-noite às margens do Solimões. In: Revista Épicas. Ano 4, N. 8, Dez 2020, p. 119-137. ISSN 2527-080-X. DOI: http://dx.doi.org/10.47044/2527-080X.2020v8.119137

\title{
CONTEMPLAÇÃO NAS SOMBRAS: O GUESA DE SOUSÂNDRADE E A MEIA-NOITE ÀS MARGENS DO SOLIMÕES
}

\author{
CONTEMPLATION IN SHADOWS: SOUSANDRADE'S GUESA AND \\ THE MIDNIGHT AT THE MARGINS OF THE SOLIMÕES
}

\author{
Vinicius Ferreira Barth ${ }^{1}$ \\ Universidade Federal do Paraná (UFPR)
}

RESUMO: Este trabalho busca analisar o episódio que narra o sonho do Guesa à meia-noite nas margens do rio Solimões, passagem que está presente no canto primeiro da épica panameríndia $O$ Guesa, de Joaquim de Sousândrade. O trecho, que antecipa a tópica épica da "descida ao inferno" ocorrida durante a Dança do Tatuturema no canto segundo, explicita algumas das influências exercidas sobre a voz do poeta em termos formais e temáticos. Esse estudo tentará identificar, através do texto poético, algumas dessas influências, bastante variadas e que reúnem aspectos da poesia épica - clássica, renascentista e moderna - da lírica e da literatura romântica e indianista, para culminar num objeto de valor singular dentro da poesia brasileira. O Guesa, índio da tribo muísca, personificação do deus Sol e representante do projeto panameríndio de Sousândrade, sofre à meia-noite uma metamorfose: assemelha-se a Lúcifer e a Prometeu, e canta sua melancolia tal como Baudelaire às margens do mitológico rio Lete. Palavras-chave: $O$ Guesa, literatura romântica, indianismo.

ABSTRACT: This article aims to analyze the episode that narrates the Guesa's midnight dream on the banks of the Solimões River, a passage that is present in the first book of Joaquim de Sousândrade's pan-Indian epic $O$ Guesa. This part, which anticipates the epic topic of the "descent into hell" that occurs during the Dance of Tatuturema in the second book, shows some of the literary influences over the poet's voice in formal and thematic aspects. This study

\footnotetext{
${ }^{1}$ Mestre em Letras pelo programa de Pós-Graduação em Letras da Universidade Federal do Paraná (2013) e Doutorando no mesmo programa, orientado pelo Prof. Dr. Alessandro Rolim de Moura. E-mail: viniciusbarth@gmail.com
} 
will try to identify, through the poetic text, some of these influences, quite varied and assembling aspects of epic poetry - classical, renaissance and modern - of lyric and of romantic and Indianist literature, culminating in an object of singular value within Brazilian poetry. Guesa, a Muisca Indian, personification of the Sun-god and representative of the pan-Indian project of Sousândrade, undergoes a metamorphosis at midnight: he resembles Lucifer and Prometheus, and sings his melancholy just like Baudelaire on the banks of the mythical Lethe.

Keywords: $O$ Guesa, romantic literature, Indianism.

\section{Introdução}

Joaquim de Sousândrade, poeta maranhense que viveu no século 19, representa um movimento único na poesia brasileira. Poeta épico e lírico, clássico e moderno, permaneceu obscurecido por toda a sua vida e por grande parte do século 20. Sua poesia, por vezes mergulhada na dicção romântica e por vezes hermética e de difícil acesso em tempos posteriores de sua carreira, demonstra um estilo que representa importante transição na poesia brasileira, e que, no entanto, é pouco observada como tal.

Antecipando elementos da poesia moderna observados em autores como Pound, Sousândrade mostra-se um autor intimamente ligado a estilísticas correntes na Europa e nos Estados Unidos, provavelmente conhecedor de nomes como Walt Whitman, Emerson, Longfellow e Heredía (Lobo, 2005, p. 121). Ademais, traz em sua poética influências muito fortes da épica clássica e renascentista, aproximando sua diç̧ão de autores como John Milton, cuja influência no Guesa é notável.

Tendo proposto o ambicioso projeto de compor uma épica, projeto este que exigiu vários anos de trabalho e sucessivas publicações, Sousândrade se coloca em estreita sintonia com os autores de sua época e de sua região, ao mesmo tempo em que comporta no Guesa toda uma gama de elementos de diversas "idades", fazendo de sua obra fundamental uma épica panamericana, traçando uma jornada odisseica em que seu protagonista vê, com olhos bastante críticos, a ascensão de um "novo mundo"2.

Essa jornada, que une de maneira ímpar as convenções da épica clássica ao século 19 e à ascensão da modernidade, é percorrida por seu protagonista de maneira enormemente reflexiva e heroica, pois ao mesmo tempo em que se viaja, pondera-se ou lamenta-se sobre o que se vê.

\footnotetext{
${ }^{2}$ A saber, a ascensão da modernidade e da República, simbolizada pelos Estados Unidos, país que é primeiramente admirado pelo poeta, dada suas convicções republicanas, para depois ser duramente criticado, principalmente através do episódio do inferno de Wall Street.
} 
Os "infernos", lugares do absurdo e do ridículo, assim como do assustador e do trágico, concentram-se em dois momentos-chave para o enredo, sendo especialmente significativos: Tatuturema (O Guesa, canto 2) mostra o quanto Sousândrade encontra-se distante da poética vigente no Brasil de representar os índios como heróis de cavalaria, colocando-os nesse inferno de absurdidade e reviravolta ${ }^{3}$; o inferno de Wall Street ${ }^{4}$ (O Guesa, canto 10), por outro lado, mostra Nova York e o desmoronamento de uma crença na república. Tais momentos na poesia de Sousândrade são, portanto, fundamentais para a construção do seu pensamento enquanto poeta crítico e moderno. Pela expressão verbal quase incompreensível do caos e do absurdo, em uma poesia que se apresenta de difícil acesso, o autor nos apresenta uma de suas características mais notáveis.

Irei me deter no canto 1 d'O Guesa (que tem um total de doze cantos), mais especificamente no episódio que se inicia com o sonho do Guesa a partir da meia-noite às margens do rio Lete/Solimões. Nele observamos alguns elementos de importante figuração contemplativa, que leva a poesia enunciada pela voz do protagonista aos terrenos do umbroso e infernal, e, por vezes, moderno. Encontraremos, por exemplo, um paralelo muito estreito que liga a poesia do Guesa à de Baudelaire, além de presenciarmos o próprio personagem tornar-se um símile de Lúcifer durante essa noite sombria.

Mas antes disso, vale nos informarmos a respeito da biografia do autor, e também de seu contexto de produção e influências.

\section{Breve notícia sobre o autor}

Sousândrade, originalmente Joaquim de Sousa Andrade, nasceu em 9 de julho de 1832 na fazenda de Nossa Senhora da Vitória, próxima do rio Pericumã, situada no município de Guimarães, estado do Maranhão. Faleceu em 21 de abril de 1902, em São Luís. Seus pais eram fazendeiros abastados que pertenciam à nobreza de Alcântara (Moraes, 1979, p. ix). Morreram cedo, deixando órfãos Joaquim e sua irmã Ana, causando também a prematura dispersão da

\footnotetext{
${ }^{3}$ Incluindo-se também nesse episódio considerações bastante críticas a respeito do período final do Império brasileiro.

${ }^{4}$ Assim nomeado pelos irmãos Campos na ReVisão de Sousândrade.
} 
fortuna da família. Conjectura-se ainda que Sousândrade tenha passado sua infância e adolescência com tios e primos em Alcântara (Lobo, 2005, p. 33) 5 .

Moraes supõe que Sousândrade tenha cursado Humanidades no Liceu Maranhense de São Luís antes de partir para o Rio de Janeiro, e de lá para a Europa, onde teria estudado Engenharia de Minas e/ou Letras na Sorbonne entre 1854 e 1856 (Moraes, 1979, p. x). Em 1857 o poeta retornou ao Rio e publicou sua obra de estreia, Harpas Selvagens.

Empreendeu também uma viagem ao Amazonas, que certamente trouxe grande influência à escrita de trechos do Guesa, e voltou em 1861 ao Maranhão, onde se casou com D. Mariana de Almeida e Silva. Passou a residir na mansão à margem do rio Anil, que nomeou como Quinta Vitória, em homenagem à fazenda em que nasceu. Em 1871, partiu para os Estados Unidos no barco a vapor North American, residindo em Manhattanville, próxima a Nova York, até 1885. Durante esse período, lançou, em 1874, o primeiro volume das Obras poéticas, contendo os cantos 1 a 4 de $O$ Guesa errante, 48 poemas de Eólias e 45 de Harpas Selvagens. Em 1876, publicou o segundo volume de $O$ Guesa errante, com os cantos 5 a 7, e em 1877 o terceiro, com o canto 8, que na edição definitiva se tornou o canto 10. Colaborou ativamente com o periódico em língua portuguesa $O$ Novo Mundo, chegando a ser secretário e até vice-presidente da sociedade mantenedora (Espínola, 2008, p. 177). Em seu retorno ao Brasil, em 1885, contornou a América do Sul pelo Pacífico, chegando a conhecer a Colômbia, o Equador, o Peru, o Chile, a Argentina e o Uruguai, o que forneceu ao poeta inúmeros elementos para compor os cantos 11 e 12 do poema. "No dia 19 de abril de 1888, é feito o depósito legal da edição definitiva de O Guesa, em Londres, editado por Cooke \& Halsted"' (Ibid.). Há alguma polêmica em torno da data exata da fixação dessa edição definitiva, mas é certo que o poema tenha sido publicado entre 1885 e 1888. Diz Cuccagna sobre a vida política de Sousândrade após seu retorno ao Brasil:

Quando em 15 de novembro de 1889 foi proclamada a República, Sousândrade tinha 57 anos e se preparava para viver uma nova fase da sua vida. Agora que a nova pátria republicana - o "Novo Éden", como ele alegoricamente a chamava no poema homônimo de 1888-1889, publicado em 1893 - se tornara uma realidade concreta, era oportuno destinar todas as energias à sua organização e atuação teórico-práticas, procurando não trair, o quanto possível, as expectativas que tinham sido alimentadas

\footnotetext{
${ }^{5}$ Lobo se baseia em trechos do Guesa que contêm tons autobiográficos. Embora seja indiscutível a presença desses elementos na obra de Sousândrade, não pretendo me ater a conjecturas baseadas em informações extraídas de excertos de poemas. Assim, enumerarei algumas informações que julgo pertinentes, mas sem levar em conta as possibilidades inverificáveis que encontram documentação apenas em versos do Guesa.
} 
pela sua consecução. O poeta, por sua parte, empenhou-se em fazê-lo pelo novo estado federado do Maranhão e principalmente pela sua capital, onde exerceu, de janeiro a agosto de 1890, o cargo de prefeito e onde se ocupou do progresso e do desenvolvimento da educação pública e privada (CUCCAGNA, 2004, p. 168).

Até morrer, viveu na mansão da Quinta Vitória, na ilha de São Luís, ensinando a língua grega no Liceu Maranhense. Em 1899, sua mulher e sua filha deixaram-no para ir viver em Santos. Em 21 de abril de 1902 foi encontrado agonizante em sua mansão por seus alunos, tendo sido transportado para o Hospital Português, tendo morrido no mesmo dia.

A redescoberta de sua poesia se deu sobretudo a partir de 1960, com o trabalho dos irmãos Campos na ReVisão de Sousândrade.

\section{Elementos de contexto e estilo}

É importante que façamos aqui uma contextualização do poeta em seu período de produção, que é de dicção predominantemente romântica, para que a partir disso analisemos suas implicações na composição do Guesa e dos episódios de mais difícil classificação. Sem pretender discutir minuciosamente o período, intento apenas esboçar alguns elementos que se fazem presentes na análise do poema. Pensando principalmente em termos de temática, temos no cerne da produção romântica a figura do $e u$, daquele que por meio de sua expressão procura a evasão da sociedade por não ser capaz de resolver seus conflitos (Bosi, 2006, p. 93). Cria-se o mito do herói e da Nação, e os povos que buscam autonomia cultural ancoram-se nessas figuras patrióticas para consolidarem suas próprias unidades. "O homem romântico reinventa o herói, que assume dimensões titânicas (Shelley, Wagner) sendo afinal reduzido a cantor da própria solidão (Foscolo, Vigny)" (Ibid., p. 95).

Assim, o crescimento da épica como elemento de afirmação de uma cultura local (pensando em exemplos como o Kalevala na Finlândia e os Poemas de Ossian na Escócia, baseados em tradições seculares) somado a produções épicas românticas originais como a de Byron (Childe Harold's Pilgrimage) e, em alguma medida, de Shelley, formam um panorama muito importante para a germinação da narrativa do Guesa que Sousândrade viria a desenvolver. Luiza Lobo cita o prefácio "Memorabilia" de Sousândrade, presente na edição nova-iorquina de 1876 do poema, em que o próprio autor define os elementos da sua obra (Lobo, 2005, p. 120): "nada 
tendo do dramático, do lírico, ou do épico, mas simplesmente da narrativa". Interessante, pois veremos o quanto Sousândrade incorpora a tradição épica em sua obra, ao mesmo tempo em que por meio da poesia lírica constrói trechos de forte subjetividade e páthos amoroso. Os irmãos Campos consideram a respeito dessa mesma colocação do poeta (Campos, 2002, p. 46): “é lícito reconhecer, não obstante, uma interpretação de todas essas linhas, num sentido muito próximo da moderna concepção do poema longo". Outro elemento de identificação entre a poesia sousandradina e a poesia romântica europeia é o da reapropriação da figura de Prometeu: mártir, rebelde, exilado e punido. Em poucas palavras, a personificação do herói romântico.

Ao pensarmos nas principais características do Romantismo brasileiro e em seus autores, é impossível não lembrarmos quase imediatamente das temáticas indianistas e das tentativas de construção da identidade nacional, baseadas numa idealização do indígena como figura simbólica da nação. De acordo com Campato Jr., “(...) foi consensual a noção de que a literatura brasileira começou a adquirir consciência mais apurada, madura e sistemática de autonomia em relação à portuguesa no Romantismo, quando os escritores tiveram, pelo menos, a suposição de que fundavam nossa literatura" (Campato Jr., 2008, p. 829). A Confederação dos Tamoios, de José Gonçalves de Magalhães, foi, assim, uma das tentativas de realizar a epopeia nacional. Em alguns casos, como sabemos, as obras foram inspiradas em paradigmas de heróis cavalheirescos e modelos literários europeus, como acontece em Iracema, de Alencar, por exemplo. Alencar, aliás, diz Franchetti,

(...) não estabelece a equação nacional = indígena. Para ele, como para os demais indianistas, engajados no projeto de construção do imaginário brasileiro, o nacional resulta da imitação do selvagem, da apropriação da sua mitologia e do seu vocabulário e formas de dizer pelo homem civilizado, por meio da imaginação arqueológica e da pesquisa linguística. $O$ que é o mesmo que dizer que o nacionalismo indianista em literatura é uma espécie de exotismo temporal, de exotismo de assunto local, exotismo de tema autóctone (FRANCHETTI, 2008, p. 1108).

O autor faz ainda uma consideração a respeito da construção do exotismo atrelado ao modelo literário europeu, citando Antonio Candido:

Antonio Candido (...) retomou essa perspectiva, pondo ênfase no parentesco entre o medievismo coimbrão das Sextilhas e o indianismo gonçalvino, cuja função principal 
não seria dar a conhecer a vida indígena, mas "enriquecer processos literários europeus com um temário e imagens exóticas, incorporados deste modo à nossa sensibilidade", concluindo que, "para o leitor habituado à tradição europeia, é no efeito poético da surpresa que consiste o principal significado da poesia indianista" (FRANCHETTI, 2008, p. 1109).

Dito isso, podemos observar mais atentamente o que acontecia no campo da poesia. Nome maior do Romantismo poético brasileiro, Gonçalves Dias também era maranhense e contemporâneo a Sousândrade. Sua proposta indianista incluiu em sua obra, além de poemas como Os Timbiras, I-Juca-Pirama, e as Poesias Americanas (nas quais consta O Canto do Piaga) presentes nos Primeiros Cantos, um Dicionário da língua tupi. E Dias, pouco tempo antes de Sousândrade, também viajou à Amazônia com o intuito de observar e estudar a situação dos índios. Tendo certamente exercido influência sobre o autor do Guesa, Gonçalves Dias “criou um novo tipo de poesia, ao fazer com que o índio deixasse de ser tema, personagem observada e passasse a assumir a voz lírica, a ser sujeito da enunciação" (Ibid., p. 1111). Vê-se no Guesa o quanto o protagonista-Guesa está próximo desta definição e, indo além do que fizeram Alencar ou Gonçalves Dias, Sousândrade investiu em seu índio proporções que extrapolam o nacional/brasileiro, abarcando grande parte do indianismo pan-americano em uma única figura.

Esse indianismo de Sousândrade, cujos ideais foram expostos no artigo "O Estado dos Índios", publicado no jornal nova-iorquino O Novo Mundo em 1872, misturava-se com seu posicionamento político, "republicano e democrático de oposição, (que) concordava com o governo monárquico dominante sobre o ponto nodal da questão: ocorria resolver o problema indígena dentro de um processo colonizador decididamente marcado para o desenvolvimento" (Cuccagna, 2004, p. 164). O "catequizar" do poeta ia em direção de se integrar o indígena na sociedade nacional:

O integracionismo sousandradino, com efeito, aspirava a uma sociedade igualitária, que resumisse racialmente a tradicional composição étnica da nação: o branco de derivação lusitana, o negro africano e o ameríndio, o último componente a ser recuperado. (...) Com efeito, acreditamos que a motivação sociopolítica e econômica que informa a escolha opositiva recuperação do índio/imigração europeia, seja também sustentada por uma forte incidência dos componentes nacionalístico e antieuropeu da ideologia sousandradina (CUCCAGNA, 2004, p. 167). 
A instauração da república brasileira foi acompanhada de perto por Sousândrade, principalmente depois de seu retorno de Nova York após sete anos. O inferno de Wall Street, trecho que mistura prosa e versos de metros diversos, derivados do limerick, traz críticas severas ao sistema político capitalista estadunidense, chegando a eleger o deus da riqueza e da ganância, Mammon, como divindade maior daquela sociedade. Após seu retorno ao Brasil em 1885, seguiu os acontecimentos políticos dos anos seguintes (Lobo, 2005, p. 40): a Abolição da Escravatura em 1888 e a Proclamação da República em 1889 (exaltada em seu poema Novo Éden, de 1893). Ambos os fatos, assim como a figura do próprio imperador Pedro II, foram abordados largamente no decorrer do Guesa (e principalmente nos trechos infernais, inferno de Wall Street e Tatuturema). No canto 1 , no entanto, temos mais contato com o cenário andino e com as mitologias inca e muísca, misturadas em alguma medida. Neste canto a crítica é principalmente direcionada às expedições de colonização exploratória dos espanhóis sobre o Peru, o que veio a trazer o fim da dinastia inca depois de vários séculos de hegemonia cultural.

O contato com a cultura muísca e seus rituais veio de leituras como a do texto "Colombie", contido na enciclopédia L'Univers (tomo I, "Amérique", autoria de Marie César Famin), e de Alexander von Humboldt, em Vue des Cordillères. Trechos desses dois textos servem como epígrafes ao poema. Sobre os muíscas ${ }^{6}$, o elemento mais importante que devemos levar em conta para a leitura do poema é o do sacrifício ritual realizado em honra do deus Sol, a divindade maior dessa cultura. Sabe-se que para a realização do ritual, um jovem era levado da casa dos pais, que devia ser situada nas planícies chamadas hoje de Llanos de San Juan. A vítima sacrificial era chamada então de guesa, "o errante", ou "o sem abrigo". A sua morte representaria a abertura de um novo ciclo de cento e oitenta e cinco luas.

De acordo com essa lenda, o jovem Guesa foi oferecido em sacrifício ao filho do deus solar Bochica, uma das divindades mais importantes da cultura muísca. Quando criança, o jovem escolhido para cumprir essa missão era tirado de sua família e conduzido ao templo solar de Sogamoso, onde era educado e preparado para o sacrifício. Ao completar 15 anos, o Guesa devia refazer a trajetória pela via sagrada (o Suna) realizada por Bochica. De acordo com a lenda, esse trajeto tem extrema importância para o povo muísco, pois Bochica peregrinou pelos povoados da região de Bogotá para transmitir as práticas religiosas e civis até então desconhecidas. Quando o

\footnotetext{
${ }^{6}$ Também conhecidos como Chibchas.
} 
Guesa terminava sua peregrinação pela via sagrada, era imolado pelos sacerdotes do filho do deus solar (denominados Xeques) e o seu coração era arrancado e ofertado ao sol. Esse ritual tinha como fim propiciar o equilíbrio entre o povo muísco e suas divindades. Quando o Guesa cumpria o seu dever, outro menino era escolhido para se tornar um novo Guesa, dando continuidade, assim, ao ritual sagrado (REINATO, 2008, p. 23).

Tendo clara a relação entre esse aspecto da cultura muísca e o poema sousandradino, observamos também a presença de alguns pontos da cultura inca, que apresenta em sua mitologia elementos semelhantes aos da mitologia muísca, especialmente no louvor ao Sol como divindade maior. Sousândrade inicia o canto 1 do Guesa evocando a história da invasão espanhola sobre o Peru e sobre a civilização inca.

\footnotetext{
“Nos áureos tempos, nos jardins da America infante adoração dobrando a crença

ante o bello signal, nuvem iberica em sua noite a involveu ruidosa e densa.

“Candidos Incas! (...)

(O Guesa, 1.13-6) $)^{8}$
}

Este seria o primeiro indício do projeto indianista pan-americano do poeta. Sabe-se que sobre os incas sempre reinaram imperadores, conhecidos também como Sapa Inca, que teriam descendido diretamente do sol. O sacrifício também fazia parte dos rituais religiosos incas, tanto de humanos quanto de animais. A adoração ao deus Sol, chamado Inti, era a base da religião de toda a civilização. Ao seu lado no panteão inca estariam Viracocha, louvado pela nobreza, MamaQuilla, que representa a Lua, e Illapa, deus da chuva, trovão e relâmpago (Ibid., p. 60). A observação dos céus pelos incas era comum em função de predições e oráculos, especialmente na hora de tomadas de decisões importantes.

O Guesa, personagem símbolo da união ameríndia idealizada por Sousândrade, traçará o seu trajeto de peregrinação em paralelo à trajetória do deus Sol no céu, como se vê em diversos momentos do canto 1. Há uma congregação de ideais políticos e literários, de rituais, religiões e figuras (incluindo também as importantes figuras de Jesus Cristo e Prometeu), em um único

\footnotetext{
${ }^{7}$ Mantenho a ortografia presente na edição do Guesa consultada para este trabalho.

${ }^{8}$ As edições consultadas do poema não apresentam numeração. Insiro aqui a contagem para facilitar a localização dos versos citados.
} 
"símbolo errante", que observará o mundo em seu isolamento romântico e heroico, pretendendo abandonar a sociedade para, ao mesmo tempo, salvá-la em sacrifício. Toda essa união de valores centralizados em um indivíduo acontece principalmente no plano da linguagem. A partir disso, o Guesa adentra mundos de difícil compreensão e de rica expressão. Passaremos, portanto, ao canto 1 e seus elementos noturnos e fantásticos, infernais e caóticos.

\section{Contemplação nas Sombras}

É muito importante o uso simbólico que o poeta faz de figuras ligadas à luminosidade e brancura, em oposição às sombras. Com efeito, inicia-se o poema com uma aproximação imagética dos Andes, onde são enumeradas as qualidades magnânimas da cordilheira em paralelo ao tema da invasão espanhola sobre os Incas. Encontramos nessa abertura um pouco dos elementos que desejamos discutir, como os efeitos que a luminosidade impõe ao leitor:

Eia, imaginação divina!

Os Andes

volcanicos elevam cumes calvos, circundados de gelos, mudos, alvos, nuvens fluctuando - que espetac'los grandes!

Lá, onde o poncto do kondor negreja, scintillando no espaço como brilhos d'olhos, e cae a prumo sobre os filhos do Ihama descuidado; onde lampeja da tempestade o raio; onde deserto, o azul sertão formoso e deslumbrante, arde do sol o incendio, delirante coração vivo em céu profundo aberto! (O Guesa, 1.1-12)

Vê-se, além dos Andes cobertos de gelo se assemelhando a "nuvens fluctuando", o cintilar do condor, o lampejo do raio e o céu ("azul sertão formoso") em que se incendeia o sol. Este, representando um dos símbolos maiores do poema, é constantemente associado a um coração pulsante que faz, em sua trajetória no céu, um paralelo da peregrinação do Guesa na terra. Além disso, o Sol consiste na divindade máxima tanto da mitologia Inca quanto da Muísca, a que o Guesa pertence. Essas imagens, portanto, cuja sequência é concluída com um símbolo máximo de luminosidade e divindade, compõem um cenário que acompanhará o Guesa em sua jornada. 
Simbolizam o dia e a própria vida desse viajante sacrificial. Entretanto, a própria voz do narrador prefigura o condor como sendo um anúncio de escuridão, pois a ave que cintila no espaço, e consiste num ponto destacado nesse "azul sertão", acaba por cair sobre os "filhos do lhama descuidado". Metaforicamente, Sousândrade insere nesse símile a imagem da colonização que recai sobre os Incas, então nomeados "filhos do Ihama".

A apresentação do canto, contendo, portanto, o background crítico com relação à invasão espanhola sobre os Incas, com um foco bastante ilustrativo sobre o cenário andino, mistura-se com o Guesa errando pelas matas amazônicas após ter descido a cordilheira:

E o deus no espaço, em fulgurosas vagas

repercutida a luz no céu profundo, dos Andes a descer fugia as plagas da morte o filho. O encontrareis no mundo: ora sorrindo o riso dos amores, que ao peregrino incantam corações; ora chorando as tão saudosas dores, no tum'lo debruçado das nações.

Elle entrega-se á grande natureza; ama as tribus: rodeiam-no os selvagens; trémulo o Amazonas corre; as margens ruem; os ecchos a distancia os pesa.

(O Guesa, 1.77-88)

Simbolicamente relacionado com o Sol por mais uma vez, o Guesa encontra-se em meio à selva (onde se apresentam figuras concernentes ao imaginário brasileiro, como, por exemplo, Uyara). As descrições sobre seu ambiente atual passam a correr cada vez mais através do reflexivo e do contemplativo. As imagens que o protagonista tece a respeito da natureza parecem por demasiado claras, além de aparecerem com muita força na narrativa, contrastando constantemente com prenúncios de "sombras" ou de elementos misteriosos. Exemplo desse contraste está na menção ao "meio dia" citada abaixo, que contém não somente os opostos entre a clareza da criatura e a escuridão de seus olhos, como também relata uma situação diametralmente oposta à que veremos alguns versos mais à frente e que nos interessa em especial, que é a chegada da meia-noite.

"Flor solar! susurrantes ao meio dia 
as abelhas na selva, na espessura

reina o viver - oh! bella creatura!

A luz dos olhos teus é tão sombria!...

(O Guesa, 1.97-100)

O contraste entre dia e noite apresenta-se de forma explícita. O dia compreende o espaço da peregrinação, da jornada errante e da natureza em completa vivência e luminosidade. A noite em que adentramos com o Guesa mostra-se diferente. Torna-se o espaço da contemplação, da problemática, fazendo-se visivel, real, e o ambiente torna-se infernal, já que o rio Solimões é imediatamente relacionado ao Lete, rio da mitologia grega que se localiza no Hades e provoca o esquecimento. É, pois, "meia noite! O Guesa Errante (...) / do seu banho nocturno agora da onda / se separava" (vv. 284, 288-9). E assim se inicia uma espécie de anúncio do que se seguirá no canto 2 do poema, a descida ao inferno na dança do Tatuturema, e o narrador se detém na mudança de atmosfera que os arredores produzem com a chegada da meia-noite. Dos cabelos do protagonista, comparados ao ondular das águas enquanto secam após o banho, até o som assoviado das encostas, tudo parece mesclar-se à meia-noite infernal que o circunda. $O$ próprio Solimões torna-se pálido. A mente do Guesa passa a funcionar por outros caminhos e a divagar, tendo ele mergulhado no Lete/Solimões.

\section{(...) Assobiando os ventos}

nas encostas sonoras, Ihe enxugavam

os seus negros cabellos, que agitavam

qual ondulam sombrios movimentos

sobre o Solimões pallido. Elle escuta:

Auras surdas; diaphanas alfombras

no espaço; o resomnar da pedra bruta;

e entristeceu.

Contemplação nas sombras:

(O Guesa, 1.289-96)

E cessa aqui a voz do narrador para que se inicie um longo trecho de reflexão enunciado pela voz do Guesa. "Não foste ainda o Lethes" (v. 297), ele inicia, e insere em seguida cenas de relações dominador/dominado, sendo a primeira a do gavião-real prendendo a cobra (v. 298), e depois a de Prometeu acorrentado à terra, em "condição ingrata" (vv. 310-4). A temática, neste momento, passa a se adensar em torno de vultos, ilusões e mudez, pela voz do Guesa. 


\begin{abstract}
"Descei, raios da noite! O dia é claro, e pode mesmo ser talvez mais bello! Porém a noite etherea traz o sêllo do coração ao sentimento charo. "Quanta augusta mudez! Oh! É verdade, não é uma ilusão, que está-se ouvindo, penoso deus, ao tempo dividindo lento o horario fatal da eternidade! "Apagam-se no mundo agora as luzes, rompem-se as masc'ras e das vãs paixões os crimes s'erguem co'as exalações do impuro estagno. Como tu seduzes, deshonra! (...)

(O Guesa, 1.325-37)
\end{abstract}

A noite, relacionada à ascensão do crime e da desonra, surge após o apagar das luzes do mundo. Assim, erguem-se também a degradação (ligada a Byron eterno no v.341) e as "bellas azas de Lucifer" (v. 348) a que se assemelham as asas da andorinha que, após atravessar o turbilhão da cachoeira, é devorada pelo "abutre da dor" (v. 356). As temáticas da dor e da morte, agora mais fortes do que em qualquer momento anterior do poema, predominam por sobre os pensamentos do Guesa. Seus sonhos, perturbados pelas dimensões infernais que compreendem o espaço amazônico em que se encontra, jogam com imagens de figuras trágicas e o contraste entre o amor e a perda, as luzes e a noite. Suas reflexões diurnas, que, como vimos, foram predominantemente a respeito da dominação espanhola, tinham esta dominação como a sombra que ameaçava o horizonte, enquanto os "cândidos Incas" eram relacionados constantemente a elementos de brancura e inocência (p.e.: "leito puro e branco" v. 23; "albor ameno" v. 26; "sangue edeneo" v. 40, entre outros). Mas o momento atual, de sono em meio à selva amazônica, traz sua reflexão para as beiras do irracional, do incógnito. A selva, neste primeiro canto, nos evoca os elementos que vão configurá-la como "inferno" no canto 2. A sobreposição de imagens e a simultaneidade de pensamentos, situações, locais e sentimentos nesse sonho do Guesa às margens do rio nos lembra de elementos da poesia moderna, como a figuração de formas espaciais, comentada por Joseph Frank a respeito de obras de Pound e Eliot: 
Como poderia ser incluída mais de uma imagem em um poema? Se o valor essencial de uma imagem era sua capacidade de apresentar um complexo intelectual e emocional simultaneamente, associar imagens claramente destruiria grande parte de sua eficácia. Ou era o poema ele mesmo uma vasta imagem, cujos componentes individuais deviam ser apreendidos como uma unidade? Mas, nesse caso, seria necessário superar a consecutividade inerente à linguagem, frustrando a expectativa normal de uma sequência do leitor e forçando-o a perceber os elementos do poema como justapostos no espaço, em lugar de desdobrando-se no tempo (FRANK, 2008, p. 174).

O isolamento e a solidão passam a predominar a partir dos vv. 356-7, onde o Guesa diz serem seus prazeres "co'a natureza", pois "na tristeza / são as brisas da noite quem me afaga" (vv. 359-60). Com isso soma-se a dor do páthos amoroso, fonte de grandes sofrimentos para o protagonista. A provável evocação de Eros aqui seria então pertinente, adjetivando-o como "deus do passado" e relacionando-o às dores do isolamento. Pois nestas plagas, o "somno socegado (...) não se perturba sitibundo de amor e embriagado / na rosea taça", e, fazendo uma relação com a virgindade, "os vestaes sacrarios / não penetram-se" (v. 368-9). O amor, seja sublime ou carnal, revela-se apenas na imaginação (ou na alma, psiquê) do protagonista, pois a "alma é dupla" e, assim, os "gózos (desse deus) são solitarios". O Guesa, no seu isolamento romântico e identificação com o eu heroico, como já comentado na seção anterior, explicita a relação da dor no amor com tal condição:

"Mas, quanta dor no amor! e que afflictivos dos outros corações não se alevantam prantos d'em tôrno ao meu! que o desincantam da luz, o apartam do bailar dos vivos. "E fujo em vão: cá dentro, dentro escuto soluçar fundo... e não desagradeço; vê-se, como tão rapido anoiteço, como de sombra e solidão me enlucto.

(O Guesa, 1.373-80)

E mais à frente, dizendo ainda "do mundo despedi-me, está despido / o manto social que me trajava" (vv. 389-90). O Guesa, anteriormente assemelhado a Prometeu, aproxima-se cada 
vez mais da figura miltoniana de Lúcifer ${ }^{9}$, que culminará mais à frente em uma citação bastante clara ao Paraíso Perdido ("A noite eu sou, consumo a minha treva", v. 424) ${ }^{10}$. O "anoitecer" da psiquê do Guesa se desenrola de maneira emblemática e progressiva. Devemos notar que conforme avança sua reflexão e sua alma se adensa em meio ao amargor solitário do páthos amoroso, o protagonista, cada vez mais Lúcifer, convence-se da impossibilidade do amor risonho do passado. Os sonhos da noite sombria que envolveram o Guesa trazem-no cada vez mais diretamente a um presente frio e infernal.
(...) Dias risonhos,
"que não fazem senão que se resinta mais do negrume a sombra! Ainda eu amo:
bem vês que ao meu inferno te não chamo; ${ }^{11}$
deixa-me só, na lagryma retincta
"banhar a bella tarde, que se apaga
dos olhos meus. -Atrás ficava a França,
qual o lume saudoso; d'esperança
"onde eu era a tormenta! Eis o passado.
Quanto ao presente... o gêlo, a morte existe
fria entre mim e o mais, e mudo e triste
o céu, qual de minha alma repassado.
"Porém, que importa tudo isso?"12 (...)
(O Guesa, 1.440-52)

Tal adensamento, que torna o Guesa cada vez mais infernal (em sentido miltoniano, prenunciando também o Tatuturema) e aprofunda o contexto infernal da selva que o rodeia, chega ao seu ápice. O personagem distancia-se de si mesmo, deixando emergir cada vez mais fortemente a sua essência obscura. "Céus, de desgôsto e frio tedio, infernos!" (v. 482), e em seguida o próprio ambiente se revela como um tipo de essência desse mal circundante, dessa selva infernal: "O vento/ murmurou, qual satanica risada / que estalasse na treva." (vv. 483-5). Acontece finalmente o despertar, e o Guesa se dá conta de sua situação:

\footnotetext{
${ }^{9}$ Embora a figura de Lúcifer também possa ser facilmente aproximada à de Prometeu, dados os elementos de revolta, orgulho e recusa da submissão a uma ordenação divina superior. Nesse aspecto, todas essas figuras mostram-se relacionadas no interior do Guesa, sobrepujando-se uma à outra em determinadas situações.

10 "Which way I fly is Hell; myself am Hell;" (Paraíso Perdido, IV, 75).

${ }^{11}$ Meu grifo.

${ }^{12}$ A voz narrativa que se perde em digressões e em certa altura pergunta-se a si mesma da importância do que está sendo dito se assemelha muito à de Apolônio de Rodes, nas Argonáuticas. Dois exemplos disso nas Arg. estão em 1.648-9: "Mas por que as lendas / de Etálida é preciso que eu conte integrais?" e em 1.1220: "Mas tais assuntos me desviam do meu canto". O próprio Guesa, nos vv. 504-5, volta a se repreender das próprias digressões: "Eu falava nas coisas em que nunca / devera eu de falar", e novamente no v. 616: "mas, esqueço; me perco em vãos pensares".
} 
"Então se geram

subtil remorso e a saudade amada tal por divertimento nos fizera..."

Ora o Guesa, talvez supersticioso do deserto, das sombras, d'essas vozes

formidaveis da noite além das fozes, estremeceu e despertou medroso: que é num lucido somno que as idéas prolongam-se mais fundas em nossa alma.

“Quem s'está rindo?!... eu devo com mais calma pensar... não são tão sós mesmo as areias.... "e eu verguei ao pêso dos meus males (O Guesa, 1.485-96)

Acordado e dando-se conta dos pensamentos que o assolaram durante os sonhos, o Guesa repensa a situação do amor, que, embora devorador, será sempre bendito (v. 510). Sua reflexão estende-se por longos trechos, em tom bastante mais "claro" e apaziguador do que os anteriores. Ele se reconhece como retornando de um estágio negativo em relação ao seu despertar, livrandose dos poderes obscuros que o sobressaltaram: "Minha mãe virtuosa, ó liberdade, / do coração amor! voltei mais nobre!" (vv. 540-1). Encontra-se, assim, consciente da condição mutável do ser, das possibilidades de introspecção que as horas de isolamento se lhe permitem, podendo tornálo mais afastado da leveza da existência e mais próximo dos negros ares:

\footnotetext{
(...) se na adolescencia a carga

"do coração é leve, -oh! quanto é leve!

se as volivolas horas desparecem

na fuga esperançosa e nos parecem

as coisas rindo-se, esperai: em breve

"a sonda ao fundo toca da existência:

a lia a tolda; de incantados mares

as fadas vão-se e veem os negros ares;

(O Guesa, 1.555-62)
}

E enfim, já se aproximando dos trechos finais do canto primeiro de seu poema, Sousândrade volta a refletir sobre a morte e a condição humana da efemeridade, evocando logo de início uma situação baudelaireana, por assim dizer, num momento crucial em que sua poesia 
dá um novo salto em direção à lírica moderna. Pergunta-se o Guesa, portanto, se será por efeito da "leviana estrela do amor e da discórdia" (vv. 588-9) que ele mesmo se sente turbado. Baudelaire parece ressoar através dos versos a seguir:

"É com tacito horror que á noite madida contempla-se esta morta, pelos póros a vida transsudando em lindos, louros vermes, em que se transfigura esqualida; (O Guesa, 1.592-5)

Ideia que ecoa, de certo modo, os versos finais de Baudelaire em Une Charogne ${ }^{13}$. Tal associação torna-se ainda mais atraente se considerarmos que os dezoito primeiros poemas que viriam a integrar Les fleurs du mal saíram publicados na Revue des Deux Mondes em 1856, ano em que Sousândrade estivera em Paris (Lobo, 2005, p. 38), e este primeiro canto do Guesa data de 1858, de tal modo que é possível que tenha havido alguma influência também em questões temáticas, como da morte e da decadência, com um tipo de valorização positiva de aspectos grotescos e repulsivos da carne.

Alguns versos mais à frente, Sousândrade esclarece ainda mais a temática que desenvolve através da citação de reverteris, nos vv. 603-4 “n'este mysterio eterno - reverteris. / Lei dolorosa... terra! terra!". A alusão ao tema bíblico é clara, quando nos lembramos de "Memento homo quia pulvis es et in pulverem reverteris" ("Lembra-te homem, que pó és e ao pó retornarás"; o assunto aparece, por exemplo, em Eclesiastes 3:20). Esta é, pois, a "Lei dolorosa", e o homem retornará à "terra! terra!". E é a esta "terra", agora reassumindo o status de divindade, que o Guesa irá se dirigir. Ela pode, portanto, nutrir tanto a "mosca, o sabio, a virgem planta altiva" (v. 608), e é adjetivada como "umbroso e unico conviva, / do banquete infinito" (v. 610-11). Por fim, o Guesa interroga a Terra sobre o poder de dar e tirar as vidas de suas "degradadas creações": "quando as consomes, / n'esse teu desespêro revolvida / triste e no proprio seio a fartar fomes, / dize, não sentes fundo a dor da vida?" (v. 612-15).

Por fim, o Guesa expressa finalmente seu desejo de ser acompanhado novamente pelo Sol e pela luz diurna de sua jornada. "Que amanheça!", diz ele no v. 629, tendo expressado logo

\footnotetext{
${ }^{13}$ Alors, ô ma beauté! dites à la vermine / Qui vous mangera de baisers, / Que j'ai gardé la forme et l'essence divine / De mes amours décomposés! (em Les fleurs du mal)
} 
antes: "Quero ainda, Senhor, ver sobre a terra / o sol que accompanhava-me na serra, / que eu já subi, que já subimos tanto!". A fusão entre a figura do protagonista e a do deus Sol é realçada mais uma vez neste momento chave. É necessário que o Guesa retome a luz do seu caminho. Finda sua noite de bruxaria e inferno às margens do Solimões pálido. O Guesa, livre das alucinações sombrias que rodearam sua mente ao longo dessa noite, move-se novamente pelo dia, tendo noção bastante clara do mal que assolou sua imaginação nas horas anteriores, respirando agora as "bellas brisas" que o aguardam no final deste canto. O inferno ficou para trás, mas voltará no canto 2 durante a dança do Tatuturema, e depois novamente no canto 10. Até lá, o Guesa, tornado apenas um com o deus Sol e com a voz do narrador (ver abaixo o uso da terceira pessoa em fusão com a enunciação da voz do protagonista), move-se contente, deixando as sombras para trás como as brisas que passam por mantos etéreos.

\footnotetext{
Perfez-se da diabólica cabeça a rotação sombria: as sombras mudas "movem-se com o embalo fluctuoso de seus mantos ethereos. Bellas brisas! Assim s'expandem d'innocencia e gôzo os céus nascentes de umas faces lisas." (O Guesa, 1.630-5)
}

\section{Referências bibliográficas}

BOSI, Alfredo. História concisa da literatura brasileira. São Paulo: Cultrix, 2006.

CAMPATO JR., João Adalberto. "A Confederação de Magalhães: epopéia e necessidade cultural." In: Épicos, por Ivan (org.) TEIXEIRA, pp. 829-45. Coleção Multiclássicos. São Paulo: Edusp, 2008.

CAMPOS, Augusto e Haroldo de. ReVisão de Sousândrade. (3a ed. rev. e ampl.). São Paulo: Perspectiva, 2002.

CUCCAGNA, Claudio. A visão do ameríndio na obra de Sousândrade. Trad. de Wilma Katinsky Barreto de Souza. São Paulo: Hucitec, 2004.

ESPÍNOLA, Adriano. "Relato biográfico." In: Melhores poemas, por SOUSÂNDRADE, pp. 175-80. Seleção e notas por Adriano Espínola. São Paulo: Global, 2008.

FRANCHETTI, Paulo. "O triunfo do romantismo: indianismo e estilização épica em Gonçalves Dias." In: Épicos, por Ivan (org.) TEIXEIRA, pp. 1097-130. Coleção Multiclássicos. São Paulo: Edusp, 2008.

FRANK, Joseph. “A forma espacial na literatura moderna.” Revista InterteXto, 2008: pp. 167-98. 
LOBO, Luiza. Épica e Modernidade em Sousândrade. Rio de Janeiro: 7 Letras, 2005.

MORAES, Jomar. "Introdução." In: O Guesa, por SOUSÂNDRADE, pp. vii-xx. Intro. e org. por Jomar Moraes. São Luís: SIOGE, 1979.

RÊGO, Josoaldo Lima. Espaço, modernidade e literatura: uma leitura de "O Guesa", de Sousândrade. Dissertação de mestrado. Universidade de São Paulo: USP, 2007.

REINATO, Pedro Martins. "A própria forma do bárbaro domínio": elementos da composição poética em $O$ Guesa, de Sousândrade. Dissertação de mestrado. Universidade de São Paulo: USP, 2008.

SOUSÂNDRADE. Melhores poemas. Seleção e notas por Adriano Espínola. São Paulo: Global, 2008.

. O Guesa. Intro. e org. por Jomar Moraes. São Luís: SIOGE, 1979 